\title{
Seed controlled deterioration of three interspecific elephant grass $\times$ pearl millet hybrids
}

\author{
Marina Pozitano ${ }^{1}$, Roberto Usberti ${ }^{2}$ \\ ${ }^{1}$ Faculdade de Engenharia Agrícola, UNICAMP, Campinas, Brasil. \\ 2 Coordenadoria de Defesa Agropecuária, Caixa Postal 960, CEP: 13073-001, Campinas, SP, Brasil.
}

\begin{abstract}
In order to allow using seeds from three interspecific elephant grass $\times$ pearl millet hybrids (Original, Cutting and Grazing-types) to set pasture fields, it became necessary to analyze their performances in relation to storage conditions and controlled deterioration. Five moisture content levels and three storage temperatures $\left(40,50\right.$ and $\left.65^{\circ} \mathrm{C}\right)$ have been tested for each hybrid. Seed sub samples for each moisture content and storage temperature combination were sealed in laminated aluminum foil packages and stored at those temperatures until complete survival curves have been obtained. The recurrent selection increased seed initial quality $(\mathrm{Ki}$ ) for grazing-type population (lower and more tillered plants); however inverse results were observed for cutting-type population (higher and less tillered plants). Viability equation constants estimated for Cutting-type, Original and Grazing-type hybrids are: $K_{E}=8.417,7.735$ and 8.285; $C_{w}=5.037,4.658$ and 4.522 ; $C_{H}=0.02309,0.01969$ and $0.03655 ; C_{Q}=0.000436 ; 0.000403$ and 0.000300 , respectively. The viability equation constants for the hybrids are $K_{E}=8.033 ; C_{w}=4.662 ; C_{H}=0.02544 ; C_{Q}=0.000386$. Through the equations, it is feasible to estimate the germination percentage of a seed lot after different storage conditions.
\end{abstract}

Key Words: Pennisetum purpureum $\times$ P. glaucum, recurrent selection, viability equation

\section{Deterioração controlada de sementes de três híbridos interespecíficos de capim-elefante x milheto}

\begin{abstract}
RESUMO - Para facilitar o uso de sementes de três híbridos interespecíficos de capim-elefante $\times$ milheto (Original, Corte e Pastoreio) para a formação de pastagens, tornou-se necessário analisar o seu comportamento em diversas condições de armazenamento e deterioração controlada. Foram testados para cada híbrido cinco graus de umidade e três temperaturas (40, 50 e $65^{\circ} \mathrm{C}$ ). Em cada combinação de umidade e temperatura, as sementes foram embaladas em papel-alumínio multifoliado e semeadas periodicamente, permanecendo nas estufas até a obtenção de curvas completas de deterioração. A seleção recorrente aumentou a qualidade inicial $\left(K_{i}\right)$ na população de pastoreio (plantas mais baixas e mais perfilhadas) e o inverso ocorreu na população de corte (plantas mais altas e menos perfilhadas). As constantes obtidas para os híbridos Corte, Paraíso e Pastoreio são: $K_{E}=8,417 ; 7,735$ e 8,$285 ; C_{w}=5,037 ; 4,658$ e 4,522; $C_{H}=0,02309 ; 0,01969$ e 0,$03655 ; C_{Q}=0,000436 ; 0,000403$ e 0,000300 , respectivamente. Foi possível obter uma equação única de viabilidade para os híbridos, com constantes iguais a: $K_{E}=8,033 ; C_{w}=4,662 ; C_{H}=0,02544 ; C_{Q}=0,000386$. Essa equação possibilita estimar a porcentagem de germinação de um lote de sementes após o armazenamento em diversas condições de temperatura e umidade.
\end{abstract}

Palavras-chave: equação de viabilidade, Pennisetum purpureum $\times$ P. glaucum, seleção recorrente

\section{Introduction}

Elephant grass (P. purpureum) is a tropical forage grass species with high potential for dry matter production, which has been used either for direct animal grazing or for feeding complementation during the drought period. Its productive potential, associated to other desirable forage traits, such as palatability, vigor and persistence, have been stimulating the cultivation and the genetic improvement of the species (Souza Sobrinho et al., 2005).
Elephant grass has been thoroughly used in Brazil and contributes to milk production increase; however there have been few improved cultivars available (Pereira et al., 2001). Most elephant grass cultivars do not produce viable seeds, thus hindering its more intense use to set pasture fields. On the other hand, pearl millet (P. glaucum) presents high production of viable seeds, but with low potential for forage production.

An interspecific Pennisetum purpureum (elephant grass $) \times P$. glaucum (pearl millet) hybrid has been developed 
in 1980 at the University of Georgia, USA, aiming to obtain rusticity and high forage production of elephant grass and high production of pure pearl millet seeds; in 1995, the hybrid was introduced in Brazil with the name of Paradise, from now on called Original (Schank et al., 1996).

However, this hybrid revealed low phenotypic uniformity $( \pm 50.0 \%)$ as well as low pure seed production (5-10.0\%). Improved populations were obtained through a recurrent selection scheme during three consecutive seasons from that hybrid, resulting in two new interspecific hybrids (Cutting and Grazing-types), showing high phenotypic uniformity in the field $(\geq 80.0 \%)$ and good pure seed production $( \pm 30.0 \%)$, making feasible the establishment of new pasture fields using these seeds (Usberti Jr. et al., 2005; Usberti et al., 2005; Reis et al., 2008).

Moisture content (MC) is considered the most important factor in seed longevity, along with the storage temperature (T). According to Harrington (1972), seed viability would be doubled to each $1 \%$ reduction in $\mathrm{MC}$ or to each a decrease of $5.6^{\circ} \mathrm{C}$ in $\mathrm{T}$.

Ellis \& Roberts (1980) proposed a reliable equation to estimate the changes in seed germination percentages during storage. The objectives of this research work were to analyze seed performance of the previously mentioned interspecific hybrids during storage under controlled deterioration, aiming to preserve the initial seed quality for a longer period of time as well as to define the viability equation constants for each hybrid.

\section{Material and Methods}

This experiment has been carried out during 18 months at the Post-Harvest Technology Laboratory, School of Agricultural Engineering, Campinas State University, Brazil. Seeds from the Original hybrid and the hybrids selected by recurrent selection (Cutting and Grazing-types) were used in this experiment. The weights of the samples were 1118.3 and $1056.9 \mathrm{~g}$ of seeds without purity for Cuttingtype and Original and $775.7 \mathrm{~g}$ of pure seeds for Grazingtype, respectively.

Seed MC was adjusted at $25^{\circ} \mathrm{C}$ from initial values ( $\pm 10 \%$ ), before experimental storage, either by rehydration above water $(3 \mathrm{~cm})$ in a closed recipient or by dehydration in desiccators with silica gel. After 3-5 days at $5^{\circ} \mathrm{C}$ for moisture homogenization, seed MC was estimated in $4 \times 25 \mathrm{~g}$ pure-seed replicates using the high-constant temperature oven method (130-133 ${ }^{\circ} \mathrm{C}, 2$ hours) (ISTA, 2006).

Sub samples containing a minimum of 200 seeds for each hybrid were sealed in laminate aluminum foil packages, divided into blocks of 12 sub samples and subsequently stored in incubators maintained at 40,50 and $65^{\circ} \mathrm{C}( \pm 0.5)$ until complete survival curves have been achieved.

All seed samples showing MC lower than 3\% were humidified above water at $25^{\circ} \mathrm{C}$ for 2 days before testing in order to avoid the possibility of imbibition injury during rehydration (Ellis et al., 1988).

Germination tests were performed on $4 \times 50$ pure seed replicates, placed in plastic square boxes $(11 \times 11 \mathrm{~cm})$ over a filter paper moistened with distilled water; afterwards, the replicates were kept in incubators under $20-30^{\circ} \mathrm{C}$ alternatetemperature regime $\left(16\right.$ hours at $20^{\circ} \mathrm{C}$ and 8 hours at $30^{\circ} \mathrm{C}$, with light). Seedling counts were performed at 3 and 7 days after seeding, according to procedures established by ISTA Rules for P. glaucum species (ISTA, 2006).

TZ viability tests were not performed since preliminary results revealed the absence of seed dormancy on the hybrids (Table 1).

Seed survival curves were fitted to germination percentage results by probit transformation. The effects of $\mathrm{MC}$ and $\mathrm{T}$ on seed longevity were analyzed using multiple regressions within the generalized linear model (Hay et al., 2003).

Table 1 - Seed storage at 40,50 and $65^{\circ} \mathrm{C}$ with different MC

\begin{tabular}{|c|c|c|c|c|c|c|c|c|c|}
\hline \multirow{2}{*}{$\begin{array}{l}\text { Hybrid } \\
\mathrm{T}\left({ }^{\circ} \mathrm{C}\right)\end{array}$} & \multicolumn{3}{|c|}{ Cutting-type } & \multicolumn{3}{|c|}{ Original } & \multicolumn{3}{|c|}{ Grazing-type } \\
\hline & 40 & 50 & 65 & 40 & 50 & 65 & 40 & 50 & 65 \\
\hline \multirow{5}{*}{$\mathrm{MC}(\%)$} & - & 7.7 & 7.7 & - & 8.2 & 8.2 & - & 7.4 & 7.4 \\
\hline & - & 9.1 & 9.1 & - & 9.3 & 9.3 & - & 9.2 & 9.2 \\
\hline & 10.7 & 10.7 & 10.7 & 10.6 & 10.6 & 10.6 & 11.2 & 11.2 & 11.2 \\
\hline & 11.9 & 11.9 & - & 13.2 & 13.2 & - & 14.2 & 14.2 & - \\
\hline & 16.0 & 16.0 & - & 17.0 & 17.0 & - & 18.0 & 18.0 & - \\
\hline
\end{tabular}




\section{Results and Discussion}

Seed germination values for the different MC tested revealed no statistical difference among hybrids; the highest percentages were obtained with $9.1(68.0 \%) ; 8.2$ (79.5\%) and 17.0 (79.0\%); $9.2(71.0 \%)$ and 7.4\% MC (71.0\%) for Cutting-type, Original and Grazing-type hybrids, respectively. The lowest germination values were achieved with the lowest MC (2.1 (58.5\%), 1.9 (67.0\%) and 1.8\% MC (65.5\%) for Cutting-type, Original and Grazing-type hybrids, respectively) (Table 2). No significant interactions were detected between MC and germination percentages.

The effects of different T/MC combinations on seed storability were depicted through survival curves on Figures 1, 2 and 3, for Cutting-type, Original and Grazingtype hybrids at 40,50 and $65^{\circ} \mathrm{C}$, respectively.

The increase of seed MC caused a clear longevity reduction, which was more evident in the highest MC (16, 17 and 18\% for Cutting-type, Original and Grazing-type hybrids at 40 and $50^{\circ} \mathrm{C}$, Figures 1 and 2). The increases of the curve slopes were due to the tremendous effect of MC on seed longevity.

Moreover, the storage temperature of $65^{\circ} \mathrm{C}$ resulted in decreases in seed germination and this effect was stronger at the highest MC (10.7, 10.6 and $11.2 \%$ for Cutting-type, Original and Grazing-type hybrids) (Figure 3).

Sigma value means the number of days required for seed germination drop by one probit or the frequency of distribution of seed deaths in time (Table 3 ).

Cutting-type hybrid seeds stored at $40^{\circ} \mathrm{C}$ with $10.7 \%$ $\mathrm{MC}$ required 57 days for the germination drop by one probit, while this result was reduced to 6 and 0.5 days at 50 and $65^{\circ} \mathrm{C}$, respectively. However, when stored at 40 and $50^{\circ} \mathrm{C}$ with $16 \% \mathrm{MC}$, it was necessary 4.4 and 1.6 days for the same purpose $(\log 4.4=0.64, \log 1.6=0.20)$. Original hybrid seeds stored at 40 and $50^{\circ} \mathrm{C}$ with $17 \% \mathrm{MC}$ presented sigma values of 2.8 and 1.4 days $(\log 2.8=0.45, \log 1.4=0.15)$. For Grazing-type hybrid seeds stored with $18 \%$ MC, these

Table 2 - Germination percentages $(\mathrm{G})$ for each MC at the beginning of the experiment (without storage period)

\begin{tabular}{|c|c|c|c|c|c|}
\hline $\begin{array}{l}\mathrm{MC} \\
(\%)\end{array}$ & $\begin{array}{c}\text { Cutting-type } \\
\text { G }(\%)\end{array}$ & $\begin{array}{l}\mathrm{MC} \\
(\%)\end{array}$ & $\begin{array}{c}\text { Original } \\
\mathrm{G}(\%)\end{array}$ & $\begin{array}{l}\mathrm{MC} \\
(\%)\end{array}$ & $\begin{array}{c}\text { Grazing-type } \\
\text { G }(\%)\end{array}$ \\
\hline 2.1 & $58.5 \mathrm{a}$ & 1.9 & $67.0 \mathrm{~b}$ & 1.8 & $65.5 \mathrm{a}$ \\
\hline 9.1 & $68.0 \mathrm{a}$ & 9.3 & $73.0 \mathrm{abc}$ & 9.2 & $71.0 \mathrm{a}$ \\
\hline 10.7 & $63.5 \mathrm{a}$ & 10.6 & $70.5 \mathrm{ab}$ & 11.2 & $70.5 \mathrm{a}$ \\
\hline 11.9 & $61.5 \mathrm{a}$ & 13.2 & $77.0 \mathrm{ac}$ & 14.2 & $70.0 \mathrm{a}$ \\
\hline
\end{tabular}

Means followed by different letter ( $\mathrm{s}$ ) in the columns are statistically different at $\mathrm{P}<0.05$.

Table 3 - Distribution frequency of seed deaths in time (sigma), in hermetic storage at 40,50 and $65^{\circ} \mathrm{C}$ with different $\mathrm{MC}$

\begin{tabular}{|c|c|c|c|c|c|c|c|c|c|}
\hline \multirow[t]{3}{*}{ MC (\%) } & \multicolumn{9}{|c|}{ Log sigma } \\
\hline & \multicolumn{3}{|c|}{ Cutting-type } & \multicolumn{3}{|c|}{ Original } & \multicolumn{3}{|c|}{ Grazing-type } \\
\hline & $40^{\circ} \mathrm{C}$ & $50^{\circ} \mathrm{C}$ & $65^{\circ} \mathrm{C}$ & $40^{\circ} \mathrm{C}$ & $50^{\circ} \mathrm{C}$ & $65^{\circ} \mathrm{C}$ & $40^{\circ} \mathrm{C}$ & $50^{\circ} \mathrm{C}$ & $65^{\circ} \mathrm{C}$ \\
\hline 7.4 & & & & & & & & 1.53 & 0.66 \\
\hline 7.7 & & 1.67 & 0.43 & & & & & & \\
\hline 8.2 & & & & & 1.31 & 0.41 & & & \\
\hline 9.1 & & 1.38 & 0.26 & & & & & & \\
\hline 9.2 & & & & & & & & 1.45 & 0.28 \\
\hline 9.3 & & & & & 1.28 & 0.23 & & & \\
\hline 10.6 & & & & 1.89 & 1.03 & 0.08 & & & \\
\hline 10.7 & 2.13 & 1.03 & 0.04 & & & & & & \\
\hline 11.2 & & & & & & & 1.95 & 1.12 & -0.05 \\
\hline 11.9 & 0.94 & 0.62 & & & & & & & \\
\hline 13.2 & & & & 0.84 & 0.46 & & & & \\
\hline 14.2 & & & & & & & 0.81 & 0.49 & \\
\hline 16.0 & 0.64 & 0.20 & & & & & & & \\
\hline 17.0 & & & & 0.45 & 0.15 & & & & \\
\hline 18.0 & & & & & & & 0.63 & 0.01 & \\
\hline
\end{tabular}



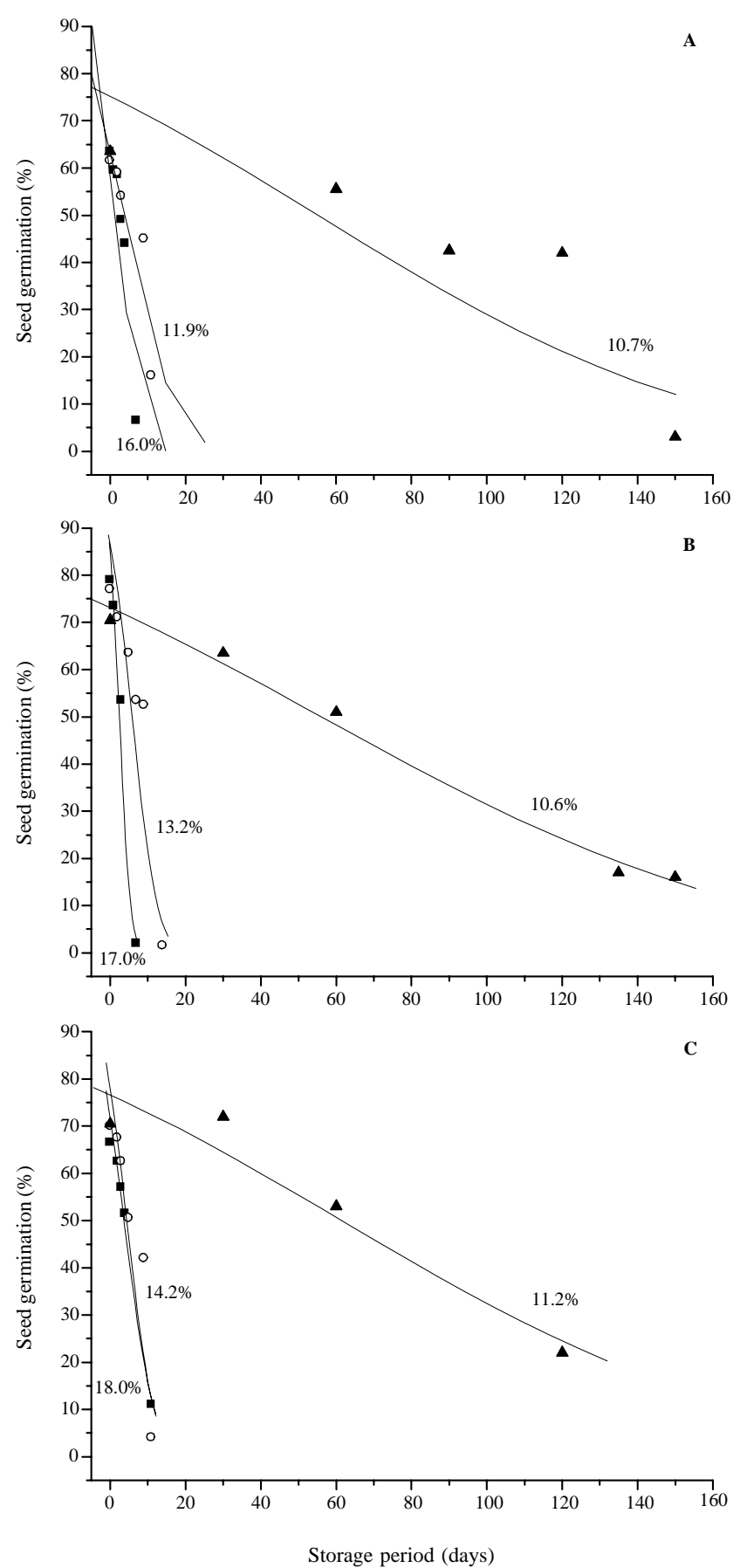

Figure 1 - Survival curves at $40^{\circ} \mathrm{C}$ for Cutting-type (A), Original (B) and Grazing-type (C). Lines represent the curves and symbols the germination percentages.

values were 4.3 days at $40^{\circ} \mathrm{C}(\log 4.3=0.63)$ and 1.03 days at $50^{\circ} \mathrm{C}(\log 1.03=0.01)$.

$K i$ value (seed lot initial quality, in probit) means the common origin point of the survival curves at the $\mathrm{Y}$-axis; however, these values were not responsible for the different performances observed among hybrids during storage (Table 4).
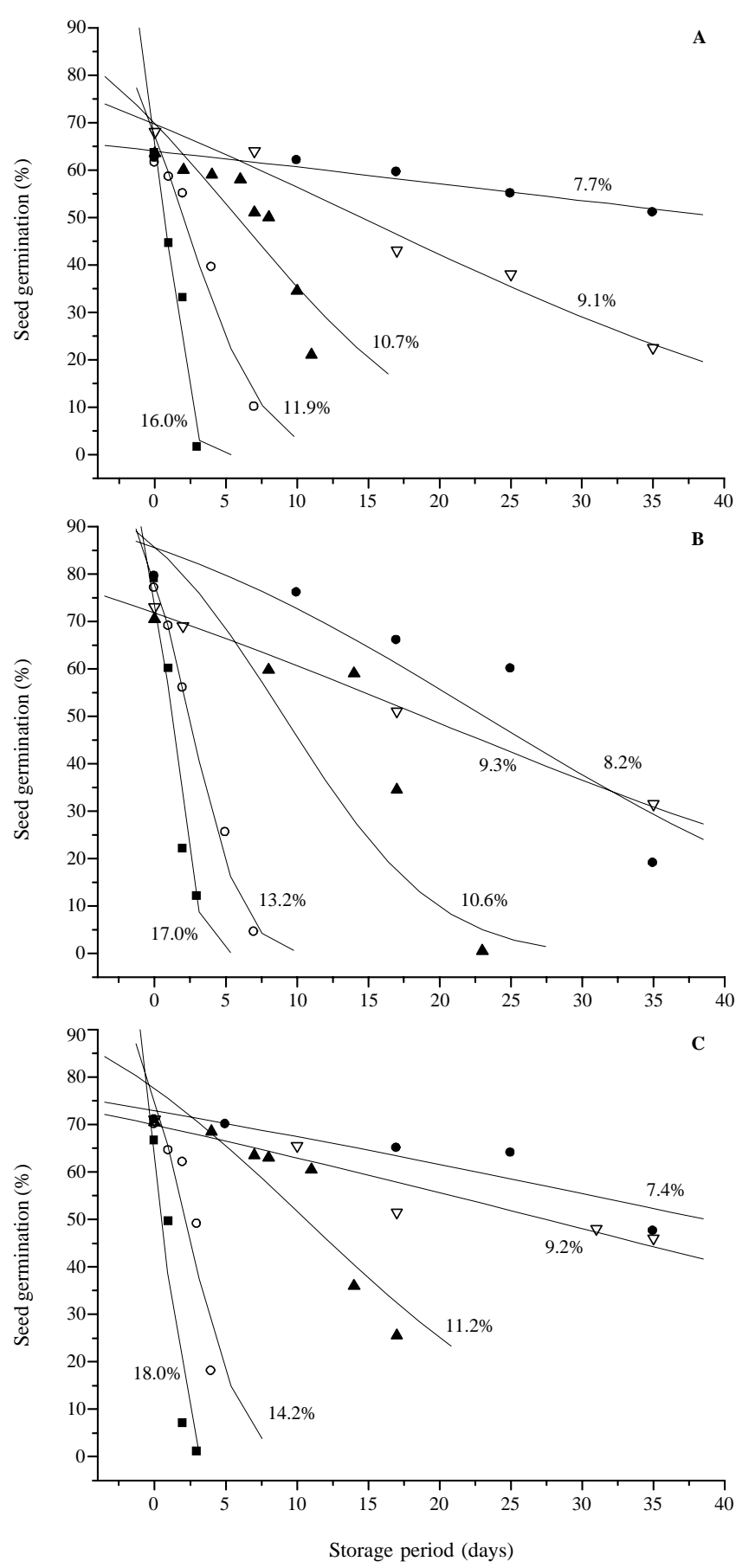

Figure 2 - Survival curves at $50^{\circ} \mathrm{C}$ for Cutting-type (A), Original (B) and Grazing-type (C). Lines represent the curves and symbols the germination percentages.

The analyses of the effect of the interaction among $\mathrm{MC}, \mathrm{T}$ and storage period revealed similar results for hybrids, with statistical differences for storage period and for the interaction among storage period and MC/T ( $F$ values of 10.8 and $19.3 ; 31.3$ and 22.6; 6.0 and 30.6, for Cutting-type, Original and Grazing-type hybrids, respectively); however, no statistical differences were 

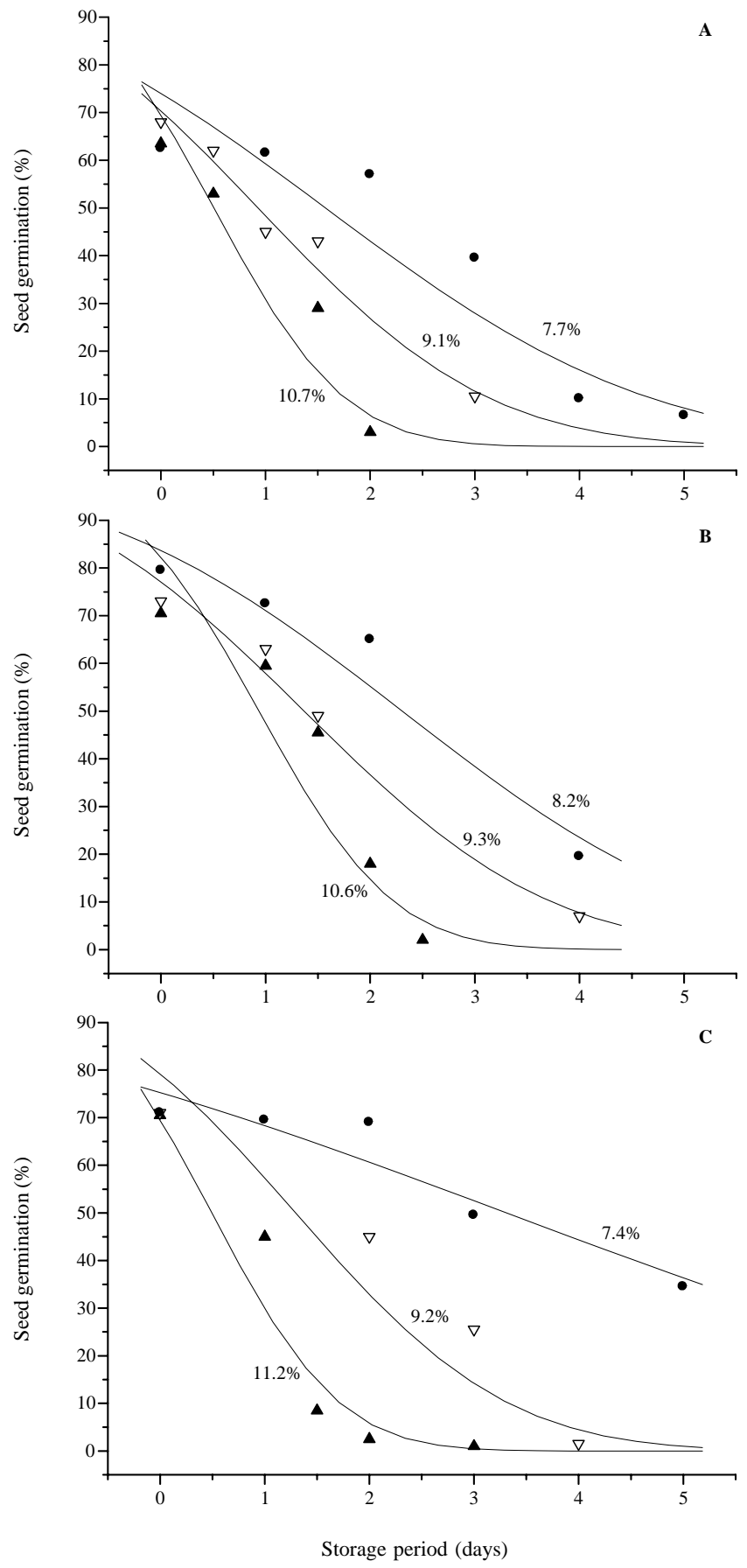

Figure 3 - Survival curves at $65^{\circ} \mathrm{C}$ for Cutting-type (A), Original (B) and Grazing-type (C). Lines represent the curves and symbols the germination percentages.

detected for the MC/T interaction ( $F$ values of $0.18,0.48$ and 0.12 ). These results allowed an accurate estimation of the viability equation constants for each hybrid.

The residual deviances for the hybrid survival curves at $50^{\circ} \mathrm{C}$ were analyzed to give the best fit to the viability equation and revealed no significant reductions in the deviances after removal of the highest and lowest $\mathrm{MC}$ values. This procedure has not been carried out at $40^{\circ} \mathrm{C}$ and $65^{\circ} \mathrm{C}$, since only three survival curves have been obtained at these $\mathrm{T}$.

Statistical analyses on the survival curves slopes (reciprocal of sigma) for each $\mathrm{MC} / \mathrm{T}$ combination have shown the same performance for the hybrids, i.e., significant differences for $\log \mathrm{MC}$ and $\mathrm{T}$ ( $F$ values of 4.57 and 20.39; 15.46 and $50.95 ; 13.33$ and 32.74 , for Cutting-type, Original and Grazing-type hybrids, respectively); however, no statistical differences were detected for the $\log \mathrm{MC} / \mathrm{T}$ interaction ( $F$ values of $0.79,2.78$ and 0.92 ).

The logarithmic relationships between $\mathrm{MC}$ and sigma for each hybrid after storage at 40,50 and $65^{\circ} \mathrm{C}$ were displayed in Figure 4. The slopes of curves at 50 and $65^{\circ} \mathrm{C}$ were similar for hybrids; however, curves at $40^{\circ} \mathrm{C}$ revealed no parallelism in comparison with the other $\mathrm{T}$, since they have been calculated for only three MC (Table 1), due to the fact that it would be necessary a long time to achieve complete survival curves with the lowest seed MC.

The viability equation constants were estimated for each hybrid analyzed (Table 5), since no statistical differences were detected for the $\mathrm{MC} / \mathrm{T}$ interaction. The values obtained for constants $K_{E}$ and $C_{w}$ were similar among hybrids; moreover, the values for constants $C_{H}=0.02309,0.01969$ and $0.03655 ; C_{Q}=0.000436,0.000403$ and 0.000300 appear to be close to those reported by Dickie et al. (1990), after analyzing 359 survival curves from eight species $\left(C_{H}=0.0329 ; C_{Q}=0.000478\right)$.

The performance of hybrids under different T/MC combinations were statistically analyzed and the results revealed no significant differences between hybrids, as well as between hybrid/log MC interactions, with $F$ values of 1.71 and 0.68 , respectively. Thus, it was feasible to estimate a viability equation for hybrids, as follows:

$v=K i-\mathrm{p} / 108.033-4.662 . \log \mathrm{m}-0.02544 . \mathrm{t}-0.000386 . \mathrm{t}^{2}$

Ellis \& Hong (2007) stored seeds of 12 crop species hermetically at different environments (2-25\% MC and $0-50{ }^{\circ} \mathrm{C}$ ) and reported that no differences were detected between the viability constants of crops $\left(K_{E}=8.033\right.$; $\left.C_{w=} 5.540\right)$, which were very close to those estimated in this experiment.

Figure 5 displays the logarithmic relationship between $\mathrm{MC}$ and sigma for seeds from the three hybrids stored at 40,50 and $65^{\circ} \mathrm{C}$. In a practical view, considering a seed sample with $11 \% \mathrm{MC}$ stored at $25^{\circ} \mathrm{C}$, with initial viability of $70 \%$ (probit $=0.52$ ), the viability would drop to $9.6 \%$ (probit $=-1.30)$ after one year and the sigma value would be 200 days.

Considering a controlled one-year-storage at $50 \%$ $\mathrm{RH}, 25^{\circ} \mathrm{C}$ and initial seed viability of $70 \%$, the sigma values 

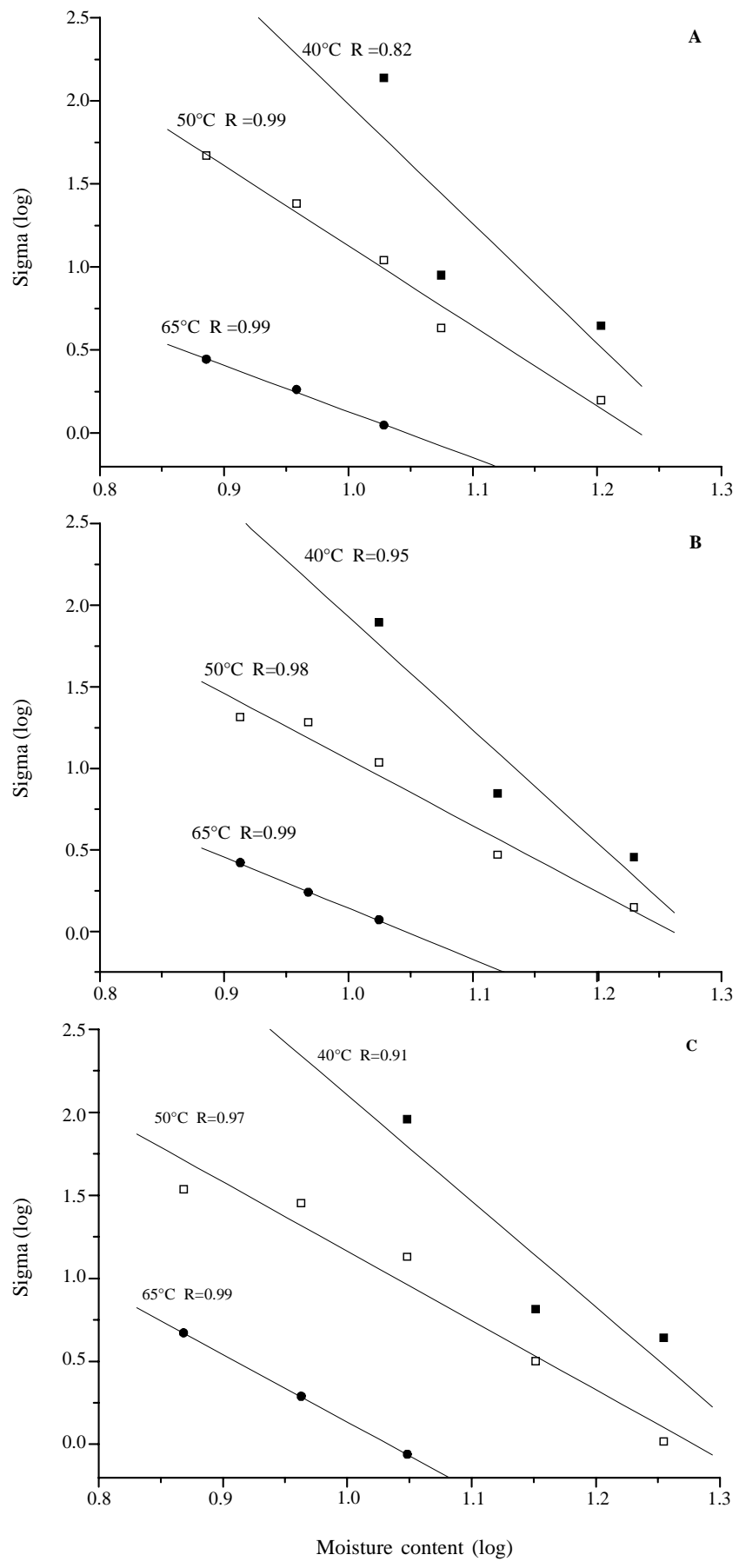

Figure 4 - Logarithmic relationships between seed MC and sigma for Cutting-type (A), Original (B) and Grazing-type (C). Lines represent the linear regression with common origin values.

Table 4 - Ki (seed lot initial quality) values for each hybrid

\begin{tabular}{lccc}
\hline Hybrids & $K i$ (probit) & Standard deviation & Germination $(\%)$ \\
\hline Cutting-type & 0.4944 & \pm 0.02051 & 69.1 \\
Original & 0.8360 & \pm 0.02220 & 80.2 \\
Grazing-type & 0.6759 & \pm 0.02205 & 75.9 \\
\hline
\end{tabular}

Table 5 - Viability equation constants for each hybrid

\begin{tabular}{lccc}
\hline Hybrid & Cutting-type & Original & Grazing-type \\
\hline$K_{E}$ & 8.417 & 7.735 & 8.285 \\
$C_{w}$ & 5.037 & 4.658 & 4.522 \\
$C_{H}$ & 0.02309 & 0.01969 & 0.03655 \\
$C_{Q}$ & 0.000436 & 0.000403 & 0.000300 \\
\hline
\end{tabular}

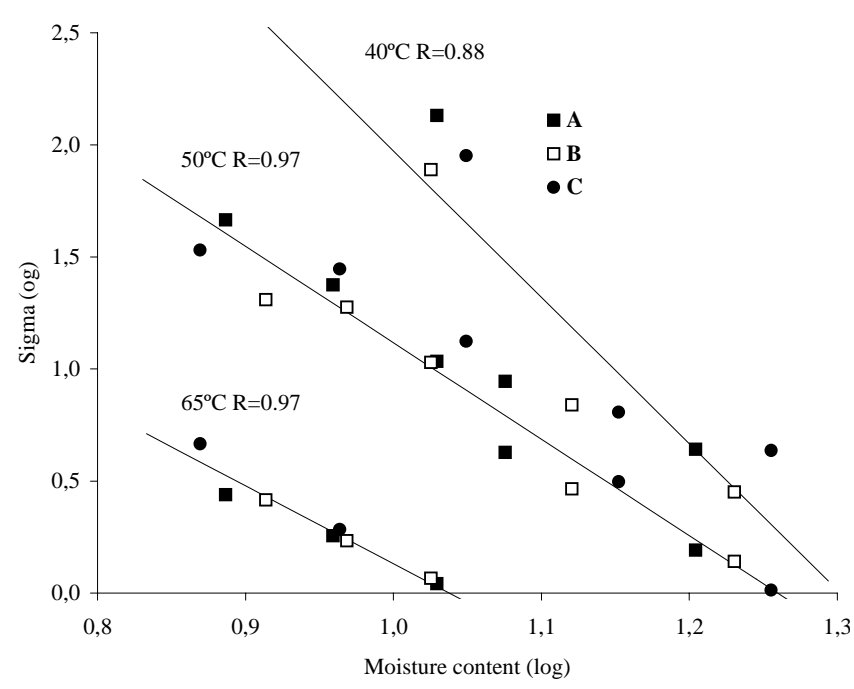

Figure 5 - Logarithmic relationships between seed MC and sigma for Cutting-type (A), Original (B) and Grazing-type (C). Lines represent the linear regression with common origin values.

estimated for Eucalyptus grandis W.Hill (Fantinatti \& Usberti, 2007) and Brachiaria brizantha (Usberti, 2006) were 295 and 714 days, respectively, while in this research, the interspecific hybrids would require 396 days for the viability drop by one probit. The final seed viabilities estimated would be 24.2,51.1 and 34.5\% for Cutting-type, Original and Grazing-type hybrids, respectively and the variations observed were probably due to the different chemical compositions among species, which influence significantly their seed storability.

Thus, through these equations, it would be feasible to estimate the germination percentage of a seed lot after different storage conditions.

\section{Conclusions}

The hybrids present different $K i$ values (initial germination percentages). The viability constants $\left(K_{E}, C_{w}\right.$, $C_{H}$ and $C_{Q}$ ) have been successfully estimated for hybrids and separately for each hybrid. 


\section{Acknowledgements}

Thanks to CNPq and CAPES (Brazilian Research Agencies) for financial support and the grant for the first author as well as the company Matsuda Seed and Animal Nutrition for supplying the seeds.

\section{Literature Cited}

DICKIE, J.B.; ELLIS, R.H.; KRAAK, H.L. et al. Temperature and seed storage longevity. Annals of Botany, v.65, p.197-204, 1990.

ELLIS, R.H.; HONG, T.D. Quantitative response of the longevity of seed of twelve crops to temperature and moisture in hermetic storage. Seed Science and Technology, v.35, n.2, p.432-444, 2007.

ELLIS, R.H.; ROBERTS, E.H. Improved equations for the prediction of seed longevity. Annals of Botany, v.45, p.13-30, 1980.

ELLIS, R.H.; HONG, T.D.; ROBERTS E.H. A low moisture content limit to logarithmic relations between seed moisture content and longevity. Annals of Botany, v.61, p.405-408, 1988.

FANTINATTI, J.B.; USBERTI, R. Seed viability constants for Eucalyptus grandis. Brazilian Journal of Agricultural Research, v.42, n.1, p.111-117, 2007.

HARRINGTON, J.F. Seed storage longevity. In: KOZLOWSKI, T.T. (Ed.). Seed biology. New York: Academic Press, 1972. v.3, p. 145-245.

HAY, F.R.; MEAD, A.; MANGER, K. et al. One-step analysis of seed storage data and the longevity of Arabidopsis thaliana seeds. Journal of Experimental Botany, v.54, p.993-1011, 2003.
INTERNATIONAL SEED TESTING ASSOCIATION - ISTA. International rules for seed testing. Zurich: 2006. 462p. PEREIRA, A.V.; VALLE, C.B.; FERREIRA, R.P. et al. Melhoramento de forrageiras tropicais. In: NASS, L.L.; VALOIS, A.C.C.; MELO, I.S. (Eds.) Recursos genéticos e melhoramento de plantas. (Genetic resources and plant improvement). Rondonópolis: Fundação Mato Grosso, 2001. 1183p.

REIS, M.C.; SOUZA SOBRINHO, F.; RAMALHO, M.A.P. et al. Allohexaploid pearl millet $\mathrm{x}$ elephantgrass population potential for a recurrent selection program. Brazilian Journal of Agricultural Research, v.43, n.2, p.195-199, 2008.

SCHANK, S.C.; DIZ, D.A.; HOGHE, P.J. et al. Evaluation of pearl millet $\mathrm{x}$ elephantgrass hybrids for use as high quality forage for livestock. Soil and Crop Society of Florida Proceedings, v.55, p.120-121, 1996.

SOUZA SOBRINHO, F.; PEREIRA, A.V.; LEDO, F.J.S. et al. Agronomic evaluation of interespecific hybrids of elephant grass and pearlmillet. Brazilian Journal of Agricultural Research, v.40, n.9, p.873-880, 2005.

USBERTI, R. Performance of tropical forage grass (Brachiaria brizantha) dormant seeds under controlled storage. Seed Science and Technology, v.35, n.2, p.402-413, 2006.

USBERTI, R.; USBERTI JR., J.A.; AGUIAR, R.H. et al. Effects of a recurrent selection scheme, applied to an interspecific hybrid Pennisetum purpureum Schum. (elephantgrass) x Pennisetum glaucum (L.) R. Br. Stuntz (pearl millet), on several seed quality parameters. In: INTERNATIONAL GRASSLAND CONGress, 20., 2005, Dublin, Ireland. Proceedings... Dublin: 2005. p.62.

USBERTI JR., J.A.; USBERTI, R.; ALCANTARA, P.B. et al. Yield and quality parameters of an interspecific hybrid Pennisetum purpureum Schum. (elephantgrass) x Pennisetum glaucum (L.) R. Br. Stuntz (pearl millet). In: INTERNATIONAL GRASSLAND CONGRESS, 20., 2005, Dublin, Ireland. Proceedings... Dublin: 2005. p.96. 